\title{
EHMTI-0077. Obesity-related intracranial hypertension in the rat - a possible idiopathic intracranial hypertension (IIH) model?
}

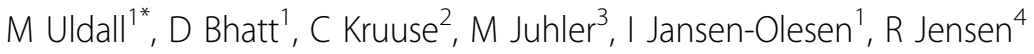 \\ From 4th European Headache and Migraine Trust International Congress: EHMTIC 2014 \\ Copenhagen, Denmark. 18-21 September 2014
}

\section{Background}

Idiopathic intracranial hypertension (IIH) is a condition of increased intracranial pressure (ICP) without identifiable cause. The majority of IIH patients are obese, which suggests a connection between CSF regulation and obesity. However, the pathophysiological mechanisms remain widely unresolved.

\section{Aim}

To develop a long-term ICP monitoring method and investigate ICP in lean and obese rats. We also aimed to clarify if any ICP difference could be attributed to changes in some well-known ICP modulators; retinol and arterial partial pressure of $\mathrm{CO} 2(\mathrm{pCO} 2)$.

\section{Methods}

ICP was measured in six obese and six lean Zucker rats with a newly developed epidural ICP monitoring method over a period of 31 days. Furthermore, arterial pCO2 and serum retinol were measured in blood samples from each animal.

\section{Results}

Obese rats had significantly elevated ICP-levels compared to lean controls on all recording days $(\mathrm{p}<0.0001)$. Serum retinol (lean: $10.54 \pm 0.36$, obese: $11.70 \pm 0.91, \mathrm{p}=0.35$ ) and arterial pCO2 (lean: $37.17 \pm 1.58$, obese: $41.25 \pm 1.80$, $\mathrm{p}=0.16)$ did not differ between the two groups.

\section{Conclusion}

Obesity-related intracranial hypertension in rats is not related to altered $\mathrm{pCO} 2$ levels or retinol metabolism.

${ }^{1}$ Research Institute Glostrup, Danish Headache Center, Glostrup, Denmark Full list of author information is available at the end of the article
This indicates that the increase in ICP might be related to molecular changes in the brain caused by the adipose state. Although further studies are warranted, obese Zucker rats could potentially constitute a model for IIH.

No conflict of interest.

\section{Authors' details}

${ }^{1}$ Research Institute Glostrup, Danish Headache Center, Glostrup, Denmark. ${ }^{2}$ Department of Neurology, Herlev Hospital, Herlev, Denmark. ${ }^{3}$ Department of Neurosurgery, The National Hospital Rigshospitalet, Copenhagen, Denmark. ${ }^{4}$ Department of Neurology, Danish Headache Center, Glostrup, Denmark.

Published: 18 September 2014

doi:10.1186/1129-2377-15-S1-F29

Cite this article as: Uldall et al: EHMTI-0077. Obesity-related intracranial hypertension in the rat - a possible idiopathic intracranial hypertension (IIH) model? The Journal of Headache and Pain 2014 15(Suppl 1):F29.

\section{SpringerOpen ${ }^{\circ}$}

( 2014 Uldall et al; licensee Springer. This is an Open Access article distributed under the terms of the Creative Commons Attribution License (http://creativecommons.org/licenses/by/2.0), which permits unrestricted use, distribution, and reproduction in any medium, provided the original work is properly cited.
Submit your manuscript to a SpringerOpen ${ }^{\circ}$ journal and benefit from:

- Convenient online submission

- Rigorous peer review

- Immediate publication on acceptance

- Open access: articles freely available online

- High visibility within the field

- Retaining the copyright to your article 